\title{
PHYSICO-CHEMICAL AND SENSORY PROPERTIES OF A CHEESE-LIKE PRODUCT FROM THE BLEND OF SOYMILK AND ALMOND MILK
}

${ }^{*}$ Arise, A. K., ${ }^{1}$ Opaleke, D. O., ${ }^{1}$ Salami, K. O., ${ }^{2}$ Awolola, G. V., and ${ }^{1}$ Akinboro, D. F.

1Department of Home Economics and Food Science, University of Ilorin, Nigeria

2Department of Industrial Chemistry, University of llorin, Ilorin, Nigeria

*Corresponding Author: abimbolatemi@gmail.com

\begin{abstract}
In this study, the possibility of producing a cheese-like product from the partial substitution of soy milk with almond milk was investigated. The extracted almond milk was mixed with soy milk in a variable proportion of $10: 90,20: 80,30: 70,40: 60,50: 50$, and the control is soya milk alone $(0: 100)$ to produce a cheese-like product. Control and partially substituted cheese-like samples were stored in a refrigerator at a temperature of $4^{\circ} \mathrm{C}$ and examined for proximate, total titrable acidity, $\mathrm{pH}$, total solid and sensory properties. The total titrable acidity of the cheese was between $0.23 \%$ and $0.33 \%$, representing a significant increase in total titrable acidity from $0.23 \%$ to $0.33 \%$. The $\mathrm{pH}$ increased with increase in the almond milk in the cheese, which varied between 6.45 and 6.90. The proximate composition ranged from $25.67 \%-29.97 \%$ for protein, $22.79 \%-26.45 \%$ for moisture, $30.58 \%-36.99 \%$ for fat, $7.02 \%-14.61 \%$ for carbohydrate, $1.20 \%-1.79 \%$ for ash, and $0.90 \%-2.03 \%$ for fibre. Protein and fat contents increased with increase in almond milk substitution, while carbohydrate and ash content decrease with increasing almond milk substitution. Sensory evaluation revealed a significant difference $(p<0.05)$ in colour, taste, texture and overall acceptability, influenced by the varying proportions of added almond milk. However, there is no significant difference in aroma. The blend with 30\% almond milk and $70 \%$ soy milk was most acceptable to panelists. The study showed the potential of almond milk as an alternative source of milk in cheese making with improved nutritional value and increased acceptability for the consumer.
\end{abstract}

Keywords: Cheese-like product, Soy-almond Cheese-like, Soy milk, Almond milk 


\section{INTRODUCTION}

Cheese is a fermented curdled dairy product, which is a semi-solid substance formed when milk coagulates through the action of micro-organisms, heat or enzyme activity (Nazim et al., 2013). It is made by coagulating either whole milk, part-skim (low fat) milk, skim milk, or cream by removing much of the liquid portion while retaining the coagulum and the entrapped milk solids (Balogun et al., 2016). Cheese is an excellent source of protein, fat, and minerals such as calcium, iron and phosphorus, vitamins and essential amino acids, and is, therefore, an important food in the diet of both young and old people (Oladipo and Jadesimi, 2012). In addition, it has been reported that the type of milk used, the manufacturing and ripening procedures have an effect on the nutritional composition of the cheese (Nazim et al., 2013). Cheese contains moderately small amounts of water-soluble constituents (whey protein, lactose, and water-soluble vitamins), which are mainly distributed in whey. None of the milk constituents are completely retained in the cheese and new substances such as salt can be added (Nazim et al., 2013).

Milk for cheese can be obtained from either animal source such as cows, goat, sheep, and buffalos. The milk from animal sources is expensive, as a result of this, its use for cheese is now limited. Therefore, the continuous search for alternative protein source in other to combat protein the energy-malnutrition in developing countries continues. This search has led to research efforts focusing on finding alternative sources of protein mainly from vegetable sources which are cheaper and affordable. Legumes such as soymilk and Bambara milk may be an alternative protein source (Siddhuraju et al., 1996). In addition to low cost, soy cheese (a soy milk product) has nutritional and health benefits because it contains no cholesterol, lactose and only small amounts of saturated fatty acids (Nazim et al., 2013). Interestingly, the cheese-like product has been obtained from blends of coconut milk and soymilk. The cheese-like product was generally acceptable and more nutritious compared to the one made solely from soy milk (Adejuyitan et al., 2014).

Almond milk is a milky and creamy drink made from ground almonds. This milk is extracted from the almond nut. Generally, almond has nutritional value and many health benefits. Almond has been reported to control the risk of diseases like obesity, type 2 diabetes and cardiovascular disease (Grundy et al., 2016). There is an increase in demand for plant-based drink due to the prevalence to animal milk protein allergies and increased interest in soy milk and almond milk due to their nutritional value (Al-Tamini, 2016: Falola et al., 2017). Furthermore, almond milk has a balanced nutritional composition in terms of protein, fat, fibre and vitamins. The fundamental reason for processing milk into cheese is to preserve a perishable food and to turn it into a stable and storable product. Consequently, to provide food varieties. Therefore, this study aims to 
produce a cheese-like product from soy milk and almond milk and to evaluate the resulting product for its immediate physicochemical and sensory properties

\section{MATERIALS AND METHODS}

\section{Materials}

Soybean seeds and almond seeds were obtained from Ipata market, Ilorin, Kwara State. Good quality almond and mould free seeds were selected. The chemicals used were of food and analytical grade and were obtained from Department of Home and Food Science, University of llorin, Kwara State.

\section{Methods}

\section{Production of Almond milk}

The method of Al-Tamimi (2016), was used with some modifications. Briefly, the almond nut was soaked for 12 hours for easy removal of the husk. $1000 \mathrm{ml}$ of water was added to 500 grams of almond nut and blended in a blender to obtain a fine texture. The blended almond nut was then filtered with a muslin cloth and the filtrate was collected into a clean container and then covered.

\section{Production of Soy milk}

Soy milk was obtained according to the method of Oloye (2014), with some modifications. 1000g of soybean was weighed and sorted. It was washed and soaked for 12 hours. The soaked soybean was then milled with a blender into a slurry and filtered with a muslin cloth. Thereafter, the filtrate was collected into a clean container and then covered, while the shaft was discarded.

\section{Production of Almond-soy cheese}

Soymilk and almond milk were mixed together at a different ratio of $90 \%$ soymilk: $10 \%$ almond milk, $80 \%$ soymilk: $20 \%$ almond milk, $70 \%$ soymilk: $30 \%$ almond milk, $60 \%$ soymilk: $40 \%$ almond milk, $50 \%$ soymilk: $50 \%$ almond milk and $100 \%$ soymilk (control). Each ration was subjected to boiling for 15 minutes. After boiling, $250 \mathrm{ml}$ of coagulant whey (fermented water from maize slurry 'ogi') was added to curdle the milk. It was poured into a muslin cloth and pressed to separate the whey from the cheese. After the drainage was complete, salt was added to it for taste. Then hydraulic press was used for the complete removal of the whey and formation of wanted shape. The stiffed curdled cheese was then cut into pieces by use of knife into preferred shapes and 
size, fried in hot oil as described as by Adejuyitan et al., (2014). The cheese was then allowed to cool and ready for consumption or packaging.

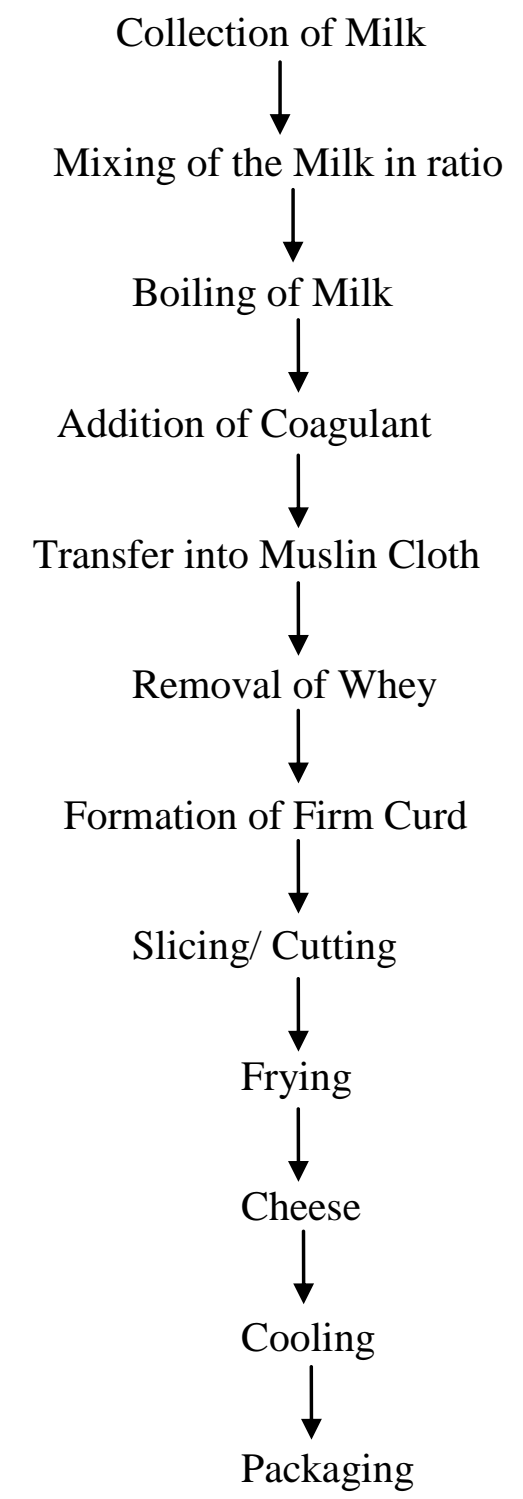

Figure 1: Flowchart of production of soy-almond cheese 


\section{Chemical analysis}

Standard methods of Association of Official Analytical Chemists (AOAC, 2000) were used to determine the moisture content, crude protein, crude fat, crude fibre, ash, $\mathrm{pH}$, total titrable acidity and total solid of the samples. The carbohydrate content was calculated by difference.

\section{Sensory Evaluation}

The organoleptic properties of the cheese-like product including taste, appearance, aroma, texture and overall acceptability were assessed by 50 untrained panelists who were regular cheese consumers. They were randomly selected and requested to assess the cheese-like product using a nine-point hedonic scale (1 and 9 representing "extremely disliked" and "extremely liked" respectively). The data were analyzed using Analysis of Variance (ANOVA)

\section{Statistical Analysis}

SPSS 16.0 was used to statistically analyse the data obtained from the study. Results obtained were triplicate determinations and were subjected to an analysis of variance to determine the significant differences among the samples at $p \leq 0.05$. The means were separated using the Duncan test.

\section{RESULTS AND DISCUSSION}

The total titrable acidity, pH and total solids of the soy-almond cheese and control are presented in Table 1. The total titrable acidity of the cheese samples ranges from $0.23 \%-0.33 \%$, SAM 1 which is the control has the highest value while SAM 6 ( $50 \%$ soymilk:50\% almond milk) has the lowest value of total titrable acidity. These results are in agreement with the report of Balogun et al., (2016), where coconut milk was used for cheese production. The pH values of the samples range from $6.45-6.90$. pH increased with an increase in the level of almond milk substitution. The total solid content ranged from $73.55 \%-75.51 \%$. There was no wide difference because the cheese samples were filtered to remove the whey-like content, thereby reducing the moisture content and increasing the total solid content. 
Table 1: Physicochemical composition of soy-almond cheese.

\begin{tabular}{lrll}
\hline Samples & \multicolumn{1}{c}{$\mathrm{pH}$} & TTA & Total solid \\
\hline SAM 1 & $6.45 \pm 0.70^{\mathrm{c}}$ & $0.33 \pm 0.00^{\mathrm{a}}$ & $73.55 \pm 0.41^{\mathrm{c}}$ \\
SAM 2 & $6.47 \pm 0.03^{\mathrm{c}}$ & $0.30 \pm 0.00^{\mathrm{bc}}$ & $73.56 \pm 0.70^{\mathrm{ab}}$ \\
SAM 3 & $6.65 \pm 0.17^{\mathrm{b}}$ & $0.28 \pm 0.00^{\mathrm{b}}$ & $74.23 \pm 0.41^{\mathrm{a}}$ \\
SAM 4 & $6.75 \pm 0.00^{\mathrm{ab}}$ & $0.27 \pm 0.00^{\mathrm{c}}$ & $74.64 \pm 0.70^{\mathrm{bc}}$ \\
SAM 5 & $6.85 \pm 0.70^{\mathrm{a}}$ & $0.25 \pm 0.00^{\mathrm{b}}$ & $75.10 \pm 0.70^{\mathrm{a}}$ \\
SAM 6 & $6.90 \pm 0.70^{\mathrm{a}}$ & $0.23 \pm 0.00^{\mathrm{b}}$ & $75.51 \pm 0.41^{\mathrm{c}}$
\end{tabular}

SAM $1100 \%$ soy cheese, SAM $290 \%$ soy milk $+10 \%$ almond milk, SAM $380 \%$ soy milk+ $20 \%$ almond milk, SAM $470 \%$ soy milk+ $30 \%$ almond milk, SAM $560 \%$ soy milk $+40 \%$ almond milk, SAM $650 \%$ soy milk $+50 \%$ almond milk. The values are expressed as the mean of three replicate samples. Values with similar superscripts in a column do not differ significantly ( $P$ $<0.05)$.

\section{Proximate composition}

The results of the proximate composition are presented in Table 2. The moisture content of the cheese samples range from $22.79 \%-26.45 \%$. SAM 6 (50\% soymilk:50\% almond milk) was found to have the lowest moisture content compared to other samples which makes it less vulnerable or susceptible to microbial attack while control (SAM1) has the highest moisture content. This result agreed with what was reported for a cheese-like product made from 50\% soymilk and $50 \%$ coconut milk (Adejuyitan et al., 2014, Balogun et al., 2012). The ash content ranged from 1.79\% to $1.20 \%$, with SAM 1 (control) having the highest ash content, the ash content denotes that the cheese samples are rich in certain minerals. Although, the ash content decreased with an increase in the level of substitution of almond milk. However, the ash content obtained in this study was higher than $0.32-0.88 \%$ reported for cheese-like product produced from coconut milk by Balogun et al., (2016). The protein content in soy/soy-almond cheese blends ranged from $25.67 \%$ to $29.97 \%$. This implies that $100 \%$ soy milk cheese (SM1) had the lowest level of crude protein, while $50 \%$ soy milk and $50 \%$ almond milk had the highest level of crude protein content. This result implies that there is an increase in the level of protein content as the level of almond milk increases. This can be attributed to the high digestible crude protein content of almond milk (Otunola et al., 2012, Al-Tamimi, 2016). Also, this result shows that a vegetable source of protein 
(such as almond milk) should be encouraged, as its consumption would help eliminate protein deficiencies. The carbohydrate content of the cheese ranged from $7.02 \%$ to $14.61 \%$, the carbohydrate content of the cheese tends to decrease as the almond milk content increases, SAM 6 ( $50 \%$ soy milk: $50 \%$ almond milk) has the lowest carbohydrate content while SAM 1 (control) has the highest carbohydrate content. The results obtained in this study differ from those of Adedokun et al., (2013), who reported an increase in carbohydrate content as Bambara milk substitution increased. However, they are in agreement with the report of Balogun et al., (2016), who reported a decrease in carbohydrate with an increase in coconut milk substitution. The fat content of the cheese samples ranged from $30.58 \%-36.99 \%$, SAM 6 has the highest fat content while SAM 1 has the lowest Fat content. The Fiber content of the cheese samples ranged from $0.90 \%-2.03 \%$, with SAM 6 having the highest fiber content of $1.83 \%$ Increase in fiber content helps to increase digestibility of the cheese (Dhillon et al., 2016).

Table 2: Proximate composition of soy almond cheese (\%)

\begin{tabular}{lllllll}
\hline Samples & Fat & Ash & Fiber & MC & Protein & Carbohydrate \\
\hline SAM1 & $30.58 \pm 0.04^{\mathrm{d}}$ & $1.79 \pm 0.01^{\mathrm{a}}$ & $0.90 \pm 0.02^{\mathrm{d}}$ & $26.45 \pm 1.62^{\mathrm{a}}$ & $25.67 \pm 0.16^{\mathrm{d}}$ & $14.61 \pm 1.49^{\mathrm{a}}$ \\
SAM2 & $32.39 \pm 0.58^{\mathrm{c}}$ & $1.57 \pm 0.02^{\mathrm{b}}$ & $1.20 \pm 0.22^{\mathrm{bc}}$ & $25.70 \pm 0.80^{\mathrm{a}}$ & $26.04 \pm 0.34^{\mathrm{c}}$ & $13.10 \pm 0.29^{\mathrm{ab}}$ \\
SAM3 & $33.00 . \pm 0.07^{\mathrm{c}}$ & $1.51 \pm 0.03^{\mathrm{b}}$ & $1.17 \pm 0.04^{\mathrm{c}}$ & $25.97 \pm 0.37^{\mathrm{b}}$ & $27.00 \pm 0.31^{\mathrm{c}}$ & $11.35 \pm 0.00^{\mathrm{b}}$ \\
SAM4 & $34.51 \pm 2.30^{\mathrm{a}}$ & $1.42 \pm 0.02^{\mathrm{c}}$ & $1.52 \pm 0.04^{\mathrm{b}}$ & $25.36 \pm 0.20^{\mathrm{b}}$ & $28.44 \pm 0.09^{\mathrm{b}}$ & $8.75 \pm 0.43^{\mathrm{c}}$ \\
SAM5 & $35.65 \pm 0.47^{\mathrm{b}}$ & $1.36 \pm 0.06^{\mathrm{c}}$ & $1.83 \pm 0.08^{\mathrm{a}}$ & $22.90 \pm 0.18^{\mathrm{c}}$ & $29.70 \pm 0.30^{\mathrm{a}}$ & $8.56 \pm 0.10^{\mathrm{c}}$ \\
SAM6 & $36.99 \pm 0.20^{\mathrm{a}}$ & $1.20 \pm 0.01^{\mathrm{d}}$ & $2.03 \pm 0.04^{\mathrm{a}}$ & $22.79 \pm 0.26^{\mathrm{c}}$ & $29.97 \pm 0.03^{\mathrm{a}}$ & $7.02 \pm 0.10^{\mathrm{d}}$ \\
\hline
\end{tabular}

SAM 1 100\% soy cheese, SAM $290 \%$ soy milk $+10 \%$ almond milk, SAM $380 \%$ soy milk $+20 \%$ almond milk, SAM $470 \%$ soy milk $+30 \%$ almond milk, SAM $560 \%$ soy milk $+40 \%$ almond milk, SAM $650 \%$ soy milk $+50 \%$ almond milk. The values are expressed as the mean of three replicate samples. Values with similar superscripts in a column do not differ significantly $(P<0.05)$.

\section{Sensory Evaluation}

The mean sensory scores for cheese samples produced with varying proportions of added almond milk are shown in Table 3. Remarkably, soy-almond cheese-like products compared favorably with the soy cheese. In fact, in terms of general acceptability, SM4 (70\% soy milk: $30 \%$ almond milk) was the most acceptable to panelists. In terms of appearance, all the cheese samples were generally acceptable. The results derived for texture showed that all samples were well accepted than the control (SAM 1). This could be because the addition of almond milk made 
the cheese-like product appears softer than the control. The aromas of all cheese samples were all well accepted to the panelists and there was no significant difference in terms of the aroma. The result revealed that SM4 (70\% soy milk: $30 \%$ almond milk) was the most preferred sample in term of taste.

Table 3: Sensory composition of almond soy cheese

\begin{tabular}{|c|c|c|c|c|c|}
\hline Samples & Taste & Colour & Texture & Aroma & Acceptability \\
\hline SAM 1 & $6.92 \pm 1.22^{a}$ & $6.90 \pm 1.40^{a}$ & $6.74 \pm 1.02^{b}$ & $6.84 \pm 1.21^{a}$ & $7.02 \pm 1.42^{b}$ \\
\hline SAM 2 & $6.94 \pm 1.40 \mathrm{a}$ & $6.78 \pm 1.40^{a}$ & $6.78 \pm 1.14^{b}$ & $6.85 \pm 1.56^{a}$ & $7.12 \pm 1.02^{b}$ \\
\hline SAM 3 & $7.06 \pm 1.30 \mathrm{a}$ & $7.04 \pm 1.29 a$ & $7.00 \pm 1.24 a b$ & $6.86 \pm 1.32^{a}$ & $7.16 \pm 1.01^{b}$ \\
\hline SAM 4 & $7.44 \pm 1.19 a$ & $7.20 \pm 1.39 \mathrm{a}$ & $7.44 \pm 1.23 a$ & $6.84 \pm 1.40^{a}$ & $7.66 \pm 1.46^{a}$ \\
\hline SAM 5 & $7.00 \pm 1.32^{\mathrm{a}}$ & $6.80 \pm 1.30^{a}$ & $6.84 \pm 1.03^{b}$ & $6.86 \pm 1.15^{a}$ & $7.04 \pm 1.11^{b}$ \\
\hline SAM 6 & $7.32 \pm 1.39 \mathrm{a}$ & $7.04 \pm 1.56^{a}$ & $6.94 \pm 1.56^{b}$ & $6.83 \pm 1.50^{a}$ & $7.12 \pm 1.04^{b}$ \\
\hline \multicolumn{6}{|c|}{$\begin{array}{l}\text { SAM } 1 \text { reps } 100 \% \text { soy milk, SAM } 2 \text { reps } 90 \% \text { soy milk } 10 \% \text { almond milk, SAM } 3 \text { reps } 80 \% \text { soy } \\
\text { milk } 20 \% \text { almond milk, SAM } 4 \text { reps } 70 \% \text { soy milk } 30 \% \text { almond milk, SAM } 5 \text { reps } 60 \% \text { soy milk } \\
\text { 40\% almond milk, SAM } 6 \text { reps } 50 \% \text { soy milk } 50 \% \text { almond milk. The values are expressed as the } \\
\text { mean of three replicate samples. Values with similar superscripts in a column do not differ } \\
\text { significantly }(P<0.05) \text {. }\end{array}$} \\
\hline
\end{tabular}

\section{CONCLUSION}

The study revealed that an acceptable cheese with high nutritional quality can be produced from soy-almond milk. This is reflected particularly in the improved protein (25.67-29.97\%) which increased with an increase in almond milk inclusion. Cheese from soy-almond can serve as nutritious food or snack and help address the problem of protein-energy malnutrition, especially in children. Sensory evaluation showed that soy-almond cheese blends $(700 \mathrm{ml}$ of soy milk, $300 \mathrm{ml}$ of almond milk) was very acceptable to panelists. Therefore, the inclusion of $300 \mathrm{ml}$ of almond milk should be encouraged in the production of soy-cheese. This will promote the utilization of almond seed, which is naturally left as the waste product. 


\section{REFERENCES}

Adedokun, I., Okorie, S., Onyeneke, E. and Anoruo, S. (2013). Evaluation of yield, sensory and chemical characteristics of soft unripened cheese produced with partial incorporation of bambaranut milk. Academic Journal of Food Research, 1(1), 14-18.

Adejuyitan, J., Olanipekun, B. and Moyinwin, O. (2014). Production and evaluation of cheese-like product from the blend of soy milk and coconut milk. Archives of Applied Science Research, 6(4), 263-266.

Al-Tamimi, J. Z. (2016). Effects of Almond Milk on Body Measurements and Blood Pressure. Food and Nutrition Sciences, 7, 466-471.

Association of Official Analytical Chemists (2000). Official methods of analysis (17th ed.), Rockville Maryland.

Balogun, M., Karim, O., Kolawole, F., and Solarin, A. (2012). Quality attributes of tapioca meal fortified with defatted soy flour. Agrosearch, 12(1), 61-68.

Balogun, M. A., Kolawole, F. L., Joseph, J., Adebisi, T. T. \& Ogunleye, O. T. (2016): Effect of fortification of fresh cow milk with coconut milk on the proximate composition and yield of warankashi, a traditional cheese. Croatian Journal of Food Science and Technology, 8(1), 10-14.

Dhillon, J., Tan, S.-Y. \& Mattes, R. D. (2016): Almond consumption during energy restriction lowers truncal fat and blood pressure in compliant overweight or obese adults. The Journal of Nutrition, 146(12), 2513-2519.

Falola, A., Salami, M., Bello, A., and Olaoye, T. (2017). Effect of yam storage techniques usage on farm income in Kwara State, Nigeria. Agrosearch, 17(1), 54-65

Grundy, M. M. L., Lapsley, K. \& Ellis, P. R. (2016): A review of the impact of processing on nutrient bioaccessibility and digestion of almonds. International Journal of Food Science and Technology, 51(9),1937:1946.

Nazim, M., Mitra, K., Rahman, M., Abdullah, A. \& Parveen, S. (2013): Evaluation of the nutritional quality and microbiological analysis of newly developed soya cheese. International Food and Research Journal, 20(6), 3373-3380. 
Oladipo, I.C. \& Jadesimi, P.D. (2012): Microbiological analysis and nutritional evaluation of West African soft cheese (wara) produced with different preservatives. American Journal of Food and Nutrition 3(1), 13-21.

Oloye, D.A. (2014): The effects of different processing techniques on the organoleptic quality of soymilk processing and storage. Journal of Food and Dairy Technology, 2(2), 8-12.

Otunola, G.A., Arise, A.K., Sola-Ojo, F.E., Nmom, I.O. and Toye A.A. (2013). The effects of addition of moringa leaf waste fibre on proximate and sensory characteristics of cookies. Agrosearch, 13(1), 69-75

Siddhuraju, P., Vijayakumari, K. \& Janardhanan, K. (1996): Chemical composition and protein quality of the little-known legume, velvet bean (Mucuna pruriens (L.) DC.). Journal of Agricultural and Food Chemistry, 44(9), 2636-2641. 